\title{
Resolving African crises: Leadership role for African States and the African Union in Darfur
}

\author{
Kelechi A. Kalu*
}

\begin{abstract}
The article examines the intersections between politics and economic development issues in the violence-ravaged Darfur region of Sudan. Also, the constraints and opportunities available to the United Nations, the African Union, and other entities to help bring the violence to an end are analysed. Within the context of the Responsibility to Protect argument and the new African Union's desire to protect citizens against government violence in Africa, the question is: Does the AU have the capability to protect citizens against government violence? With a specific focus on Sudanese Darfur, the article offers a strategic vision for reducing and hopefully ending human rights violations that have ravaged much of sub-Saharan Africa. I argue that in order for the UN and AU to fully protect citizens against government-sponsored violence, the self-empowerment of African States, regional African Organisations, non-governmental organisations, citizens and the African Union must be recognised as the first lines of defence

* Dr Kelechi Kalu is a Professor of African American and African Studies at The Ohio State University, Columbus. This article is a revised version of a paper entitled 'Darfur: In Search of Peace Consultations' prepared for the Africa Today Associates. The author is grateful to Negin Sobhani for research assistance, to Africa Today Associates, the Open Society Institute in Abuja, the Ford Foundation for sponsoring the research, and to Cynthia Cook and Chimnomnso Kalu for constructive suggestions and editorial assistance.
\end{abstract}


against government and government-sponsored atrocities against citizens. The article concludes with recommendations for ending the violence in Darfur.

\section{Introduction}

The organisation of the international political system as it currently exists privileges the rights of the state over those of individuals. The state's capacity to protect while simultaneously constraining citizens' rights reigns supreme over its territory. This relationship between the state and the citizens has made it possible for governments to claim sovereign authority over their territories including the sovereign right to relate to their citizens peacefully or with coercive force. The latter has frequently resulted in gross violations of human rights across the globe. In many African states (such as the Democratic Republic of the Congo, Sierra Leone, Liberia, Nigeria, Apartheid South Africa, Sudan, Ethiopia and Rwanda), these violations intensified following political independence and the development of the unwritten rule of non-interference in the internal affairs of member states by the moribund Organisation of African Unity (OAU). Intrastate conflicts, especially the Rwandan genocide, awakened Africans and their leaders to a central norm across the continent: the inviolable essence of human life.

Many of the states experiencing this awakening are currently ravaged by violence, disease, poor public policies and, in many instances, state incapacity to carry out the basic function of maintaining law and order to protect the citizens. Consequently, Africans and members of the international community continue to advocate for the human rights of individuals trapped within the boundaries of corrupt and inefficient states - states that are unwilling or unable to carry out their basic security functions to protect their citizens. However, both groups have largely failed to implement viable and sustainable solutions to the intractable crises in many African states. The problem is not whether some Africans and their external supporters see human rights protections, stable political systems with free market economy, and constitutional liberalism as positive variables for ending endemic crises like those in southern Sudan, Darfur, but rather the lack of sustainable and institutionalised strategies for effective governance. This article offers a strategic vision for reducing and hopefully ending gross human 
rights violations within the context of intrastate crises that have ravaged much of sub-Saharan Africa. The expected peace dividend from the end of the Cold War never materialised in sub-Saharan Africa where Western governments' preference for stability continues to privilege autocratic leaders who ascend to power through fraudulent electoral results and/or violence; e.g. the Democratic Republic of the Congo, Nigeria, and the Sudan.

The international community stood by in 1994 while over 800000 Rwandans were slaughtered with the full knowledge and support of their government. Today it has responded to the crisis in Darfur. But that response has been practically irrelevant as women, children and men are raped, dehumanised and killed on a daily basis while the major powers debate the semantics of genocide. A brief background is in order.

\section{The context of the Darfur crises}

In Sudan, like most other multi-ethnic states in Africa, the struggle for political independence rendered ethnicity quite fluid as the goal for the nationalists was the attainment of political independence from Britain and Egypt. Sudan gained her independence in 1956. However, 'seeking [...] first the political kingdom,' as Kwame Nkrumah asked Africans to do in the 1950s, did not result in statewide development - because political independence revealed the dark side of tribalism. In Sudan, and consistent with colonial practices elsewhere, the result was sustained development in one part of the country, the northern part. Scarce resources and uneven development policies and strategies caused western Sudan, Darfur, to become the worst neglected region.

M.W. Daly notes that Sudan's first scientific and only nation-wide census was conducted in 1955-56. Population data yield information that should inform policy makers of the magnitude of development problems and therefore serve as a basis for policy planning and action. But the data, as revealed from the 1955-56 census in Sudan, were fraudulently interpreted and used to privilege the Muslim North by exaggerating their representation in the national population/ institutions. The census played down ethnic differences and therefore underreported the proportion of other groups in the state for purposes of power and 
resource allocation. The resulting tension was not resolved through the political process and led to the intractable civil war in contemporary Sudan.

The census reported the Sudan's population as 10,263,000. Darfur's 1.35 million ranked third only to Blue Nile (2.7 million) and Kordofan (1.76 million); the six northern provinces comprised about 7.5 million, or 72 percent of the total, and Darfur therefore almost 18 percent of the north's and 13 percent of the Sudan's population. Of females over puberty but of childbearing age, Darfur had the highest percentage of any province -24.6 percent - and between the ages of five and puberty also the highest -11.4 percent.... The census found that a bare majority of Sudanese (51 percent) spoke Arabic at home, followed by Dinka (11 percent). Arabic was also the majority language in Darfur (55 percent); Fur (classified for census purposes as three dialects of one language, North, South and West Darfurian), was spoken at home by 42 percent (5.6 percent of the Sudan's population), and the rest spoke other languages, none of which accounted for more than 1 percent of the province's total (Daly 2007:179-180). ${ }^{1}$

Furthermore, in terms of tribe or 'nationality', the census found that 375000 of Darfur's people were Arabs (of whom 269000 were Baqqara) and 758000 'Westerners' (Fur, Masalit). Among many things, these figures indicate that Arabic had become the first language of roughly a third of those considered ethnic Fur. These and other figures relating to ethnicity, tribe, and language would later assume much more prominence in contemporary Sudanese politics (Daly 2007:180; Republic of Sudan, Ministry of Social Affairs 1958:23-24).

Population distribution was not the only factor contributing to instability in Sudan. The education and employment statistics remain relevant to today's events.

In terms of the highest school attended (by people over the age of puberty), no province of the Sudan, including even the South, had a lower percentage for intermediate school than Darfur: 0.2 percent; the figure for female was 0 .

1 See also Republic of Sudan, Ministry of Social Affairs 1958:4, 5, 7, 10. 
Likewise for secondary school attendance, no province had a worse record: the Bahr al-Ghazal and Upper Nile matched Darfur at 0.1 percent. For the Sudan as a whole, 78 percent of males over the age of puberty had received no formal schooling, and 97.3 of females; for Darfur, the figures were 65 and 99 percent respectively (Daly 2007:180). ${ }^{2}$

The data provided the government with the necessary ammunition to produce an effective national policy for all its citizens. The data should have been used for development planning, including job creation and building an intellectual infrastructure that would sustain not just Darfur and the southern Sudan, but the entire country.

Of Darfur's 350,000 males over the age of puberty, 232,000 were farmers, 38,000 nomadic animal owners, and 31,000 shepherds. There were 158 male and 37 female primary and intermediate school teachers in the entire province. Among medical practitioners, 2 were classified as 'professional' and 281 as 'semi-professional' (including 63 women). There appear to have been 783 policemen and prison wardens ( 4 of whom were women), 1 professional accountant, and 2 (males) in the field of 'entertainment.' Most women - 79 percent - were classified as 'unproductive,' and the only field in which they outnumbered men was 'Unemployed, beggars' (Daly 2007:179181). ${ }^{3}$

Given that civil war has been the norm in southern Sudan for these decades, it is reasonable to assume that not much has changed in terms of development since the sole census in 1995-56. The discovery of crude petroleum in southern Sudan has not improved the situation. However, as with other African states, the industry is largely based on expatriate employment - in this case, Chinese. Consequently, over time, with the lack of external and internal support, the historical neglect of Western Sudan by the central government ignited and intensified ethnic consciousness and marginal identity in the periphery. The strong nationalistic

2 See also Republic of Sudan, Ministry of Social Affairs 1958:19.

3 See also Republic of Sudan, Ministry of Social Affairs 1958:38-40, 54-55. 
consciousness that preceded independence died because of poor development policies by the central authorities, especially their lack of vision for building a truly nationalistic Sudanese state. The personalisation of power by the Muslim Arabs in Khartoum and their efforts to create a homogeneous Sudanese culture without requisite developmental infrastructure exacerbated the needs and desire for ethnic ties and consciousness. These expectations for ethnic unity were manifested in the formation of different groups who hoped to achieve for themselves what the dominant group within the central government historically denied them - effective and significant decision-making capacity.

The 2003 formation of the Sudan Liberation Army/Movement (SLA/SLM) in loose association with the Justice and Equality Movement (JEM) intensified the use of ethnic consciousness as a framework for demanding a seat at the national decision-making table. However, SLA/JEM strategy has changed from engaging the political process to violent attacks of government targets outside of Khartoum. Arguably, the changed strategy from negotiation to violence by peripheral groups like SLA/JEM is explained by their fear that Darfur and the Western region would be left out of the power-sharing agreements that the Government of Sudan was negotiating to end the civil war in southern Sudan. Such fear was based on the fact that the central government had repeatedly ignored requests for meetings on how best to include the Darfur region on the national development agenda.

The intensified ethnic consciousness born of political struggle for scarce resources expanded to include charges of racism against the central government, and violence targeting government facilities by 'rebels' who defended their actions by accusing the government of oppressing black Africans in preference of Arabs. The Government of Sudan responded to the informal politics and strategies by the rebels with crushing air raids targeting villages believed to be rebel strongholds. The government also enlisted the assistance of former criminals, bandits, and members of tribes with land conflicts against African tribes in Darfur. In addition to providing arms, the government did not object to other groups and individuals with different agendas who sought to exploit the crisis by joining the 'Janjaweed' in terrorising the Darfurians. The Janjaweed, or 'devils on horseback', have been labeled 'Arab' because the majority of their 
ancestry is more Arab than African - further intensifying the rigidity of the alliances in the conflict.

Originally created and supported by Libya in Western Sudan for attacking Chad, the Janjaweed are responsible for the burning and looting of villages across Darfur as well as raping, murdering, and kidnapping civilians. There are reports of instances where air raids by Sudanese Government forces are strategically followed by mop-up operations by the Janjaweed, indicating coordination between the government and the Janjaweed, contrary to government claims that armed criminals are responsible for most of the Darfur killings. Fear of the Janjaweed has forced Darfurians to leave their possessions and homes and relocate to camps for Internally Displaced Persons (IDPs), mostly in northern Darfur, and some to refugee camps in neighbouring Chad. The rise in IDPs and refugees has created what numerous groups have labeled the worst humanitarian crisis in the world. Racial and ethnic slogans, chants, and the Janjaweed's motivations as they taunt, capture, and kill the Darfurians cause many, but especially the US government, to go so far as to label the situation as genocide. A United Nations Security Council (UNSC) report on Sudan (United Nations Security Council 2007) highlights the awful results of the conflict:

The humanitarian situation in Darfur has suffered from persistent violence and overall insecurity. Over two million people are now internally displaced, while 1.9 million conflict-affected residents remain largely dependent on external aid. Approximately 107,000 civilians were newly displaced by insecurity [in] fighting between 1 January and 1 April [2007].

Thus, the Government of Sudan's policy in Darfur is to bring the conflict to an end on its own terms - largely homogenising all the ethnic groups consistent with the cultural, language and ethnic consciousness of the ruling northern elite. More significantly, given the government's willingness to negotiate a comprehensive peace treaty with the South to end the civil war, it seems clear that the strategy adopted by the Darfurians for a share of the national wealth and the government's heavy-handed response suggests the government might be more concerned about regime stability than ethnic cleansing or genocide. 
In this sense, the government's violent reaction to the Darfuri rebels might be a calculated strategy to discourage other potentially marginalised and neglected groups from taking up arms against the government. To ensure that the Darfuris are not protected from the government and the Janjaweed, the violence sponsored by the government extends to the aid and humanitarian workers in the region whose work is directly aimed at assisting civilians and providing succour. The emergence of the African Union to replace the now defunct OAU - and its odious principle of non-interference in the internal affairs of member states - thus greatly pleased the international community. The AU is seen as a new body with a new philosophy of responsibility toward citizens whose governments have failed to protect in the midst of violent crises. This so-called humanitarian intervention thesis is addressed later.

\section{Darfur and the African Union}

The African Union (AU) was established in 2002 as the successor of the Organisation of African Unity (OAU), which was established in 1963. Consistent with African leaders' general tendency to emulate Africa's former colonisers, the $\mathrm{AU}$ was the natural successor to the OAU, similar to the European Union succeeding the European Community. One wonders whether the AU is truly African in spirit and form. The OAU was established in 1963 by 31 newly independent African states in a spirit of pan-Africanism that aimed to promote economic unity, collective security (Zweifel 2006:147), and eventually, political unity. Its main strategy for dealing with African problems was to stress the principle of 'peaceful settlements of disputes' (Murray 2004:118). Without effective institutional structures and visionary leadership, its poor record on conflict resolution and management was compounded by financial, logistical, and political problems. Much of the OAU's failure was due to its policy of noninterference in states' internal affairs which weakened its ability to prevent and manage conflicts, especially civil wars. Now with 53 African states as members of the $\mathrm{AU}$, the added features of intervention, independence, checks and balances, and monitoring make the AU potentially a 'more effective, democratic, and autonomous organization' (Zweifel 2006:148). According to the former OAU Secretary-General (and current AU Special Envoy), Dr. Salim Ahmed Salim, the promise of the AU is its objectives of 'enhancing unity, strengthening co-operation 
and co-ordination as well as equipping the African continent with a legal and institutional framework, which would enable Africa to gain its rightful place in the community of nations' (Francis 2005:29). These hopeful objectives are rooted in a desire and motivation to 'enhance the cohesion, solidarity and integration of the countries and peoples of Africa' (Francis 2005:30). The core instrument for achieving the above objectives is the Constitutive Act of the African Union.

The Constitutive Act empowers states to intervene where countries fail to protect their citizens from internal conflicts. Specifically, Article 4(h) of the Principles provides: 'The right of the Union to intervene in a Member State pursuant to a decision of the Assembly in respect of grave circumstances, namely war crimes, genocide and crimes against humanity' (African Union 2000:art 4(h)). This Act must not and cannot be impeded by excuses of sovereignty which were used to avoid responsibility and action in past instances where intervention would have saved millions of lives. Some argue that member states have essentially accepted external intervention in their internal affairs in times of serious or extreme crisis by signing this Act that runs against the standard practice of non-intervention in the UN Charter (Murithi 2005:97). This document, however, while continuing to reiterate the importance of promoting peace, security, and stability for individuals and the continent also contains clauses which affirm the sovereignty, territorial integrity and independence of states exclusive of grave violations of human rights and goes so far as to prohibit the use of force or threat under the basis of non-interference (African Union 2000:art 3, 4). Despite these improvements, the AU has inherited many of the problems of its predecessor. Sceptics thus warn against prematurely assuming this new organisation will 'significantly enhance the project of uniting Africa or strengthen the capacity of states to respond to peace and security issues on the continent' (Francis 2005:30). Perhaps this fear is why the AU established the Peace and Security Council (PSC or AUPSC) to prevent, manage, and resolve conflicts in the continent. As is profoundly evident in the case of ongoing massive slaughter and displacement of certain sections of Sudanese citizens or crimes against humanity in Darfur, the strategic question - how to mobilise 
and deploy collective resources in the continent for realising the goal of conflict prevention and management - remains to be substantively unresolved.

Comprised of 15 rotating members (for either two or three year terms), the PSC has 'powers to anticipate events that may lead to genocide and crimes against humanity, recommend the intervention...impose sanctions... and follow up in terms of conflict prevention issues of human rights, among other things' (Murray 2004:125). The question may be asked, however, given the hegemonic intent in establishing the PSC and its expressed powers, what significant and substantive instrument exists to carry out its functions without constraints. That is, what functional or institutional power does the PSC have over the sovereign leaders of states who may not wish close scrutiny within their 'sovereign territory'? That Article 7 forces African leaders to realise that sovereignty does not forever remain a 'shield from intervention' (Levitt 2005:226) is not sufficient without compelling strategic military and political instruments of statecraft at the disposal of the AU to realise its stated goals of ensuring peace, security and individual human rights. Through the PSC, the AU has also authorised the creation of the African Standby Force (ASF) made up of strictly African soldiers whose responsibility, among others, is to intervene in member states where crimes against humanity as outlined in Article 4(h) above occur (African Union 2002:art 13). Again, we must ask: Based on what vertical decision structure and with what kind of logistical and human resource base will the ASF carry out its functions? Indeed, given their current role, which is limited to that of humanitarian assistance and 'alleviating the suffering of civilians in conflict areas' (African Union 2002:art 13), it is most urgent that the AU with the full endorsement of African governments, clarify the strategic vision it hopes to deploy for its lofty goals before it becomes irrelevant from incapacity as the case of Darfur is already demonstrating. However, the establishment of the PSC shows the AU's commitment to ending conflicts through the legal and political processes that protect civilians against government and government-sponsored violence. Thus, while political and financial enforcement mechanisms in the AU and PSC guidelines are clearly specified, the test of the AU's effectiveness will be the extent to which these important steps are tangibly implemented. More 
significant however, is the strategic process that moves key actors from violence to political negotiation, for example in the case of Darfur.

Given that the current structure of the AUPSC and the ASF places state sovereignty above the obligation to protect individuals, it is doubtful that the PSC will be able to carry out its functions or that the AU can intervene in a state where genocide is occurring if the state government refuses such intervention. Consequently, to achieve the goals of protecting individuals against state violence, the $\mathrm{AU}$ is more likely to succeed if it establishes an African Union Security Command (AU-SC) with a standing rapid reaction force for military intervention where the AU identifies genocide and/or other state-sponsored crimes against humanity in Africa as the first step toward engaging the political process. The AU-SC can stand alone or complement other activities by the AUPSC and the ASF. Armed and under the command of a reputable and competent leader, the rapid reaction function of the AU-SC is more likely to result in the realisation of the AU charter by elevating individual rights over state rights, thereby ensuring consistent protection of human rights in the continent.

Substantively, while state sovereignty remains essential against non-AU threats, sovereignty and human rights are enhanced within the continent to the extent that $\mathrm{AU}$ access to intrastate human rights struggles is not blocked by autocratic claims of state sovereignty. In other words, for a political process that privileges peace and robust resolution of issues of human rights, force must be compelling when government-sponsored violence remains a major obstacle to getting the actors to the negotiation table.

The effective functioning of the African Union and its constitutive units is needed to curb the crisis in Darfur. Thus, while the AU has worked closely with the international community, primarily the $\mathrm{UN}$, in attempting to alleviate some of the humanitarian conditions and convince the al-Bashir Government to allow a peacekeeping force in Darfur, the AU has only served as monitor of cease-fire since 2004 because it lacks the robust logistical and personnel presence to be effective. The argument for a more robust AU through the AU-SC is in recognition of both the African governments' desire and the international 
community's professed preferences for collective action to end genocide and government-sponsored violence against innocent civilians.

While the capacity for collective action in the international community, especially the UN, has always existed, it has not been deployed for the protection of individuals against their governments in Africa. It seems, however, that the UN has been awakened from its slumber to the suffering of Africans at the hands of their own governments, for 'at the United Nations World Summit on 17 September 2005, world leaders agreed, for the first time, that states have a primary responsibility to protect their own populations and that the international community has a responsibility to act when governments fail to protect the most vulnerable' (Jentleson 2007:582). The Responsibility to Protect international doctrine pledges 'to take collective action if national authorities manifestly fail to protect their population from genocide, war crimes, ethnic cleansing and crimes against humanity' (Jentleson 2007:583-584). While the doctrine provides hope and an enabling framework for collective action to hold governments claiming sovereignty without responsibility accountable for the atrocities committed against their own citizens, the question is: How can this collective responsibility be achieved in situations where governments fail to protect their citizens or are complicit in the atrocities committed against them? I argue that at the core of realising the $\mathrm{UN}$ and $\mathrm{AU}$ desires to protect citizens against government-sponsored violence is recognising that the self-empowerment of African States, regional African Organisations, non-governmental organisations, citizens and the African Union are the first lines of defence against government and government-sponsored atrocities against their own citizens. Internal initiation of an accountability process for the maintenance of sovereignty would make it possible for non-African states, organisations and citizens to offer effective aid for bringing genocide and other human rights violations in places like Darfur to an end.

While the African Union has its peace security functions and the desire to form a union government, it seems conflicted on the nature of the relationship between African States and their citizens. Additionally, despite its desire to, the AU lacks the logistical and political will to end crimes against humanity in 
Darfur. Cognisant of the international reality that the UN Security Council is responsible for global security and stability, African States formed the African Union Mission in the Sudan (AMIS), the only external entity on the ground in Darfur with the responsibility to protect civilians. However, because of poor capacity and lack of resources, AMIS has failed to competently execute its mission as evidenced by the continuing atrocities in the Darfur region and in the refugee camps in neighbouring states. That said, most important about AMIS is that for the first time since decolonisation, African leaders seem aware of their responsibilities to Africans as evidenced by their decision (albeit poorly executed thus far) in Darfur.

While the issues in Darfur as illustrated below are mostly economic and political in nature, they lend themselves to verifiable efforts through good faith negotiation followed by national policies aimed at their effective resolution, if the political will exists in Khartoum to do so. We will first identify the intersecting issues - national and international - in the conflict in Darfur and then offer robust strategies for how African States and the African Union can start the process of protecting the victims of human rights abuses and other atrocities in the continent.

\section{Intersecting issues in the Darfur crisis and recommendations}

The crisis in Darfur is born of several intersecting, yet separate conflicts. As Scott Straus insightfully notes, the crisis is traced to the civil war between the Islamist, Khartoum-based national government and two rebel groups - the Sudan Liberation Army and the Justice and Equity Movement - based in Darfur. ${ }^{4}$ As previously noted, the rebel groups are fighting because of economic and political marginalisation by the national government. In a sense, if the government in Khartoum had engineered a national economic and political development plan that did not marginalise any section or group in the Sudan, the SPLA/JEM would not have had verifiable reason to attack government facilities in 2003 - resulting in the national government's arming of irregular militias to quell the violence that escalated to the current level in Darfur. Similarly, the crisis in Darfur is

4 Unless otherwise noted, the discussion in this section relies on Straus 2005:123-133. 
related to the civil war that has raged in Sudan since its political independence in 1956, in which the Arab-dominated national government and its cultural and linguistic homogenisation policies in Sudan created a dyadic civil conflict that has been simplistically explained as North-South and Arab-Christian conflict in contrast to the core issue of economic and political marginalisation of the South by the northern-based government of Sudan. Under the auspices of the Intergovernmental Authority on Development (IGAD), the Sudanese government entered into negotiations with the southern rebel groups - which did not include Darfuri representatives. The peace negotiation resulted in the Comprehensive Peace Agreement that promised an end to the longest civil war in Africa. Consequently, the Darfur rebels attracted attention to their own cause of marginalisation as a strategy to mobilise ethnic, regional, continental and global attention to the poor economic and political condition.

The other dimension of the crisis is the localised nature of the race/ethnic dimensions of the conflict. As Scott Straus (2005:126) notes:

Darfur is home to some six million people and several dozen tribes. But the region is split between two main groups: those who claim black 'African' descent and primarily practice sedentary agriculture, and those who claim 'Arab' descent and are mostly semi-nomadic livestock herders. As in many ethnic conflicts, the divisions between these two groups are not always neat; many farmers also raise animals, and the African-Arab divide is far from clear. All Sudanese are technically African. Darfurians are uniformly Muslim, and years of intermarriage have narrowed obvious physical differences between 'Arabs' and black 'Africans.' Nonetheless, the cleavage is real, and recent conflicts over resources have only exacerbated it. In dry seasons, land disputes in Darfur between farmers and herders have historically been resolved peacefully. But an extended drought and the encroachment of the desert in the last two decades have made water and arable land much more scarce. Beginning in the mid-1980s, successive governments in Khartoum inflamed matters by supporting and arming the Arab tribes, in part to prevent the southern rebels from gaining a foothold in the region. The result was a series of deadly clashes in the late 1980s and 
1990s. Arabs formed militias, burned African villages, and killed thousands. Africans in turn formed self-defence groups, members of which eventually became the first Darfur insurgents to appear in 2003.

That 'Khartoum instructed the militias to "eliminate the rebellion," as Sudan's President Omar al-Bashir acknowledged in a December 2003 speech.... [And that] Army forces and the militia often attacked together, as janjaweed leaders readily admit... and in some cases, government aircraft bomb areas before the militia attack, razing settlements and destroying villages' (Straus 2005:126-127) clearly establishes the connection between the government decision to eliminate a segment of its population by virtue of who they are perceived to be - black African farmers. The ethnic cleansing, massive human rights violations and genocide evidenced by the inability of the Darfurians to protect themselves against such massive government violence calls for international protection consistent with the expressed goals of the United Nations and those of the African Union. Documents in the possession of the AU peacekeeping force in Darfur indicate the Sudanese Government is directly involved in organising and supporting the violence against the Darfurians.

According to Nicholas Kristof, one document directed the regional commanders and security officials to ensure the 'execution of all directives from the president of the republic .... [and to c] hange the demography of Darfur and make it void of African Tribes ...' [by] 'killing, burning villages and farms, terrorizing people, confiscating property from members of African tribes and forcing them from Darfur' (Jentleson 2007:446). ${ }^{5}$ From all accounts, while Darfur like the rest of Sudan has been involved in various levels of conflict since the 1950s, the intensity of the current conflict measured by the number of casualties - estimated at over 300000 deaths and over one million IDPs with hundreds of thousands more in various refugee camps outside of Sudan - was ignited by the Sudanese Liberation Army's 'surprise attack on the airport at El Fasher, the capital of North Darfur State' (Kasfir 2005:196). The Sudanese Government's swift and intense response to the SLA attack in 2003 led to an outcry of genocide in Darfur. As Gerard Prunier notes, the massive killing in Darfur have a number of explanations: (1)

5 See also Kristof 2005 and Kasfir 2005:197. 
ancient tribal conflicts reignited by droughts, (2) a counterinsurgency campaign by the government of Sudan gone wrong, (3) a deliberate policy of ethnic cleansing of African tribes to make room for Arab nomads, and (4) 'genocide ... supported by evidence of systematic racial killings' (Prunier 2006:200).

While these explanations are important singularly, collectively the timing and intensification of the killings suggest deliberate policy, strategy and motive by the Government of Sudan to consolidate its power within the country by using the SLA/Darfuris rebellion to demonstrate its resolve against other marginalised groups' future efforts to demand a peace negotiation and therefore a share of national wealth and power similar to the generous provisions in the Comprehensive Peace Agreement with the Christian South. And, as Kasfir succinctly summarises, 'One problem in isolating the government's motives is that the Darfur crisis grows out of many conflicts at the local, regional, and national levels. These conflicts involve responses to diminished natural resources, to ethnic and cultural conflict, to negotiations and the peace agreement in southern Sudan, and to the relationship of the national government with impoverished and marginalized groups throughout the country' (Kasfir 2005:197).

The foregoing makes clear that the government of Sudan organised and aided the Janjaweed - drawn mostly from marginalised Arab/Muslim communities in Darfur to attack, slaughter and displace the non-Arab Darfuris - mostly Africans but predominantly Muslims. Arguably, it is also clear that the government chose this high-handed approach to the rebels because it was already engaged in a peace negotiation process in 2003 with mostly Christian southerners against whom it had fought since 1956 and did not want to repeat the process with other marginalised groups and regions in the future.

Interestingly, the political dimension of both the Darfuri rebellion and the government's response holds the key to an effective solution to the crisis in Darfur. As articulated by intellectuals from southern Sudan, 'the central problems that pose a threat to peace and unity in the Sudan are attributable to three basic causes: (1) the dominance of one nationality over the others; (2) the sectarian and religious bigotry that has dominated the Sudanese political scene since independence; and (3) the unequal development in the country' (Akol 1987:15). 
The question is how to proceed toward the realisation of peace and stability throughout Sudan to enable its people to pursue their lives and interests. Given the intensity of the violence in Darfur, the Comprehensive Peace Agreement signed in January 2005 between the North and South, as well as the commitment of the Government of Sudan to maintaining power, resolving the Darfur crisis and indeed, fully upholding the CPA would require robust international and regional mediation between the various factions in Sudan.

\section{Toward resolution}

The international dimension of the Darfuri rebellion and therefore its partial solution is evident in the fact that the peace settlement between the Muslim government of Sudan and the Christian southern rebels was already in the minds of Washington (with the appointment of Andrew Natsios in May 2001 as Special Humanitarian Coordinator for Sudan and Senator John Danforth on September 6, 2001 as Special Envoy for Peace in Sudan - both part of President George W. Bush's conservative Christian constituency). Any hesitation on working together to resolve the age-old civil war on the part of both Washington and Khartoum was shelved following the terrorist attacks against the US in 2001, which provided President Omar al-Bashir's government - whose human rights record was largely seen as repugnant - with an unprecedented but grotesque opportunity to play the hero's part in the fight against terrorism. The Sudanese government's enthusiastic offer of support for the anti-terrorist policy can only be read as al-Bashir's government's desire not to repeat its earlier strategic error of siding with Saddam Hussein in the first Gulf War, and therefore, avoiding the polarisation of its civil war into Arab-Muslim government versus Christian southern rebels that would have increased global support to the rebels, especially from Washington if it did not make the correct choice of denouncing terror and terrorists on the global stage. As Clement Adibe (2007:26) notes,

When September 11 attacks occurred ... President Bashir firmly denounced Osama bin Laden and al Qaeda and pledged to cooperate with Washington in rooting out the terrorist menace. In Washington, Bashir's unsolicited support, like Ghaddafi's, was especially well received by Powell's State 
Department which was saddled with the task of putting together a 'coalition of the willing' on a very short notice. ... [And] 'Since 9/11, Bashir has provided the U.S. with a steady stream of much-vaunted intelligence' which has been used to track and target al Qaeda networks and funds.

Consequently, Washington rewarded the Sudanese government by supporting '... the lifting of UN sanctions against Sudan on September 28, 2001 ... and quietly quelled pending legislation for imposition of capital market sanctions ... [and for] the next two years, the Bush administration treated Khartoum as an ally in its war on terror while Bashir's security and the Janjaweed roamed Darfur with greater impunity' (Adibe 2007:26). The foregoing indicates that the United States has the moral and military force capability and credibility multilaterally or unilaterally - to nudge others toward resolving conflicts like the Darfur crisis. I would argue that the United States fails to consistently use its capacity to enhance peace and security missions in Africa; or more specifically, fails to forcefully use regional and international organisations such as the African Union and the United Nations in such projects because there are no consistent national interest imperatives in United States foreign policy toward Africa. Certainly, there is no consistent African constituency with voting power at the congressional district levels to compel action on behalf of Africa.

Similarly, the United Nations and the former Organisation of African Unity did not, as collective action institutions, intervene in the internal affairs of an African state in protection of the rights of individuals as individuals or as members of a group. Even when such intervention would likely have saved hundreds of thousands of lives as the case of Rwanda showed, the two institutions did nothing beyond engaging in rhetorical debates over state responsibilities to their citizens and whether the atrocities qualified as genocide because the interests of the elites in these institutions are largely devoid of compassion and commitment to the resolution of issues on behalf of the marginalised and disorganised victims of both structural and state-supported violence. The role of the AU, however, can be more constructive than the conflict-avoidance strategies employed by much of the Western world in Africa, and the inaction that plagues the veto-hobbled 
Security Council organ of the United Nations and the non-interference excuse for inaction by the defunct OAU.

\section{Progressive responsibility to protect argument}

While sovereign states are notorious for protecting their rights to internal action, multilateral institutions such as the United Nations with codified collective security principles have been notorious for insisting on invitation from states before intervening in a nation's internal affairs to protect entrapped citizens facing extermination as in Rwanda and the former Yugoslavia. But while powerful states such as the United States in collaboration with regional organisations such as the North Atlantic Treaty Organisation (NATO) will, if their interests are at stake, violate the UN principles as was the case in Kosovo in 1999, less powerful states and organisations such as those in sub-Saharan Africa are left to fend for themselves based on the inviolability of the principles of sovereignty - at the expense of unprotected citizens in Rwanda in 1994. It is illuminating that the US-NATO action in Kosovo in 1999 resulted in '... an unusual distinction when an independent international commission called the US-NATO intervention illegal in the sense of not having followed the letter of the UN Charter but legitimate in being consistent with the norms and principles that the Charter embodies' (Jentleson 2007:439, my italics). ${ }^{6}$

Perhaps the foregoing insight led to the formation of the International Commission on Intervention and State Sovereignty, whose 2001 report provides a theoretical basis for the responsibility to protect argument. The responsibility to protect argument (Jentleson 2007:439; Independent International Commission on Kosovo 2000) is based on the core principles that 'state sovereignty implies responsibility' and that the primary responsibility of a state is the protection of people within its territory. In situations 'where a population is suffering serious harm, as a result of internal war, insurgency, repression or state failure, and the state in question is unwilling or unable to halt or avert it, the principle of non-intervention yields to the international responsibility to protect' (Jentleson 2007:439). The responsibility to protect argument further provides

6 See also Independent International Commission on Kosovo 2000. 
for prevention of 'large scale loss of life' as its priority with as little coercive force as possible; and emphasises that the motive for intervention should be to avert human suffering.

Furthermore, the five permanent members of the UN Security Council should agree not to veto resolutions authorising the use of military force when their interests are not directly involved. Specifically, it says, 'The Security Council should take into account in all its deliberations that, if it fails to discharge its responsibility to protect in conscience-shocking situations crying out for action, concerned states may not rule out other means to meet the gravity and urgency of that situation - and that the stature and credibility of the United Nations may suffer thereby' (Jentleson 2007:439, my italics). Given that the United Nations accepted the responsibility to protect argument after both genocide and ethnic cleansing occurred in Rwanda, Bosnia and Kosovo, the Darfur crisis is the first test case for this important international norm and obligation. Thus far the test has failed either because Russia and China have material interests in Sudan and/ or because the United States has a verifiable national interest in working with the al-Bashir administration whose support for the United States' war on terrorism compels the United States to be diplomatically lenient with its allies.

An added dimension is the negotiated peace between the Sudanese government and the southern rebels to which the United States, the United Nations and the African Union were party. As a result, all three are cautious about forcing the hands of the Sudanese government, lest it renege on the provisions in the Comprehensive Peace Agreement, since the consequence would be a return to a massively destabilising war for the country and region. The problem is that the African Union's presence and argument of 'African solutions to African problems' free the United States, China, Russia and, by extension, other western powers from doing much about Darfur beyond diplomatic talk. With its 7000 troops and lacking logistical capability in Darfur the AU is unable to provide robust and credible protection for its troops or the Darfuris, some of whom continue to be killed by Sudanese government forces, rebels and the Janjaweed. 


\section{What to do?}

Clearly, the responsibility to protect argument lacks teeth and the African Union lacks the necessary force and capability to significantly help the Darfuris as is evident by the partial arrival of the negotiated 20000 additional troops in January 2008. However, it is not a cliché to say the failure to protect the Darfuris is the failure of African governments to assume full responsibility for the peoples of Africa. If we assume the $\mathrm{AU}$ is serious about privileging African peoples over state and sovereignty claims, the right to protect does provide for an effective role for a regional organisation such as the AU in cases where the UN Security Council proves ineffective. The question becomes: What does the AU need to do?

First, there has to be a peace to keep before peacekeeping forces can be brought into the region. Therefore, the constraint on reaching and keeping peace in the Sudan is directly related to the asymmetry of force between the government of Sudan and the Janjaweed on the one hand, and the fragmented and disorganised Darfuris and its various splinter groups on the other. Given the core issues for the southern Sudanese - autonomy with the right to vote for independence in a couple of years from the larger Sudanese state - peace may eventually be settled in battle. For Darfuris, economic development and political justice constitute the core issues, which unarguably lend themselves to political negotiation. Therefore, creating the space for political negotiation requires a cease-fire between the combatants. Strategically, then, deploying troops (Africans and non-Africans) with robust logistical support to force an end to the fighting is the first step to engaging in peace negotiation and implementation. In this sense, force activation and deployment are predicted to lead to acceptance of a ceasefire by both the Government of Sudan and its collaborators and the Sudanese Liberation Army and their collaborators as a precondition for peace and the concomitant negotiation/resolution of issues about justice. For an effective outcome, neither the government nor the rebels should have the power to veto the source of the troops and/or the type of logistical support available to the military intervention force. 
Following the military intervention force, the AU must take decisive steps toward bringing the Government of Sudan, the Darfur representatives, the Sudanese Liberation Army, and the Justice and Equity Movement groups together to negotiate and correct whatever identified problems exist within the framework of Sudanese law and public policy. This must include the option of comprehensively federalising the provisions of the Comprehensive Peace Agreement with southern rebels to the rest of the country. Acting boldly in convening the groups in the Darfur crisis in its headquarters or another suitable location will establish the $\mathrm{AU}$ at the forefront of the responsibility to protect protocol provisions of both the UN and the AU. It will also ensure that the AU spearheads any final peace talks and will confirm to all the dedication of African governments to the guidelines of the AU charter and its commitment to avoiding the failures of the OAU.

Given that the Sudanese government is reported to be '... inviting Arab tribesmen from Niger and Chad to occupy the lands vacated by the refugees' (The Economist 2007:55-56) in Darfur indicates at least its intent to ethnically cleanse the region and at worst, commit genocide. Because the Darfur crisis is an African problem with global implications, a basic responsibility for the AU would be to boldly and unequivocally label the crisis in Darfur as ethnic cleansing/genocide. This would include labeling the crisis a grave situation and a crime against humanity - a clear warning to the Khartoum-based Sudanese government and the Janjaweed leadership that failure to stop the large-scale violence will bring them up for charges on crimes against humanity consistent with the International Criminal Court provisions. This would have two immediate results: first, it would activate Article 4(h) of the AU's Constitutive Act requiring the organisation to take action; and second, it would avoid the definitional conflict over the term genocide and compel African governments to clearly identify their support for the AU's 
Constitutive Act to which they are signatories. ${ }^{7}$ With clear identification of the crisis as genocide/ethnic cleansing and with the presence of robust military intervention for purposes of establishing a cease-fire in the region, the AU should then place travel restrictions on the top leaders of the Government of Sudan and rebels responsible for atrocities, except for travel related to negotiation and resolution of the conflict. The strategy should include: freezing the bank accounts of all affected individuals and groups, imposing sanctions on Sudanese companies deemed to be complicit in any atrocities that the AU is attempting to bring to an end and compensating those whose actions help bring an end to large-scale violence.

In addition, recognition and recognition withdrawal can be powerful and effective tools available to the African Union for carrying out its responsibility to protect vulnerable people in situations where African governments have failed to protect the people within their territories. In this case, and beyond, social primordial identities, and therefore group identities are constructed to create space for inclusion and exclusion. This approach ensures that the Fur or Arabs will remain who they are; however, the Sudanese state may or may not survive an identity reconstruction if war erupts across the country. Thus, while states in Africa as well as their membership in the African Union may eventually survive or die, it is individual primordial identities ${ }^{8}$ that are sustained over time as the basis for recognition of our individual existence. Furthermore, the artificially or socially constructed identities are political tools that can be used for purposes of ending conflicts like those in Sudan. In the formation of social or group identities, there is always an in-group such as the African Union or the United Nations which represents the desired group identity, and the non-group members such as states that have to adjust if admitted in order to remain members of the

7 Clearly, an immediate implication of this bold action might be a threat to break up the organisation by some members, which might actually lead to the disintegration of the African Union. But it might also, on grounds of public opprobrium and support of civil society organisations, force member states to vote consistent with the provisions of the Constitutive Act to protect individuals/groups whose governments have chosen to ignore and/or violate their human and peoples' rights - a welcome relief for the emergence of truly politically independent African states!

8 This section relies on the excellent explication of Al-Baqir al-Afif Mukhtar (2007). 
group. Thus, the African Union is the core group for African states who desire membership in the group. It occupies the centre stage of the group identity, and group membership for states such as Sudan or Nigeria should depend on their behaviour. The privileges of membership should draw the non-group states to seek inclusion. As such, the AU has the power to legitimise or de-legitimise the public behaviour of states, especially with regard to their policies toward the people in their territories. The power of recognition and its withdrawal then becomes a tool that enables the $\mathrm{AU}$ to monopolise the power to recognise or withdraw diplomatic recognition from members whose actions are judged repugnant to civilised standards - especially, when such actions include ethnic cleansing and/or genocide. Indeed, the power of recognition or its withdrawal seems to be the most powerful diplomatic tool available to the $\mathrm{AU}$ and members of the UN Security Council such as the United Kingdom and France who desire to do something to end large-scale violence characteristic of ethnic cleansing/ genocide without necessarily participating in joint military intervention with the AU forces.

The power of recognition is not new as evidenced by the capacity of the United States' legislature to include or exclude states on its 'list of terrorist supporting states'. The Sudanese government was placed on this list in the 1990s and thus it sought to be excluded again when it pledged support for the war against terrorism after September $11^{\text {th }}$. Such diplomatic tools should be used by the African Union to recognise and/or withdraw recognition of African states and others whose actions support large-scale violence in the continent either through the supply of arms, the threat of the use of veto to obstruct the passage of UN Security Council resolutions on military interventions, and/or the use of state power in any form to undermine the responsibility to protect obligations of both the UN and the AU within Africa.

Structurally, the current trials by the International Criminal Court (ICC) over the 1994 Rwandan Genocide offer a precedent and an avenue for the forthcoming AU Court of Justice to be the venue and structural platform for any future trials of Africans and their leaders who commit offences against humanity as codified in the Geneva Conventions. Such sanctions and legal actions within the continent 
are likely to have a large positive impact, albeit symbolically; but they also signal Africans' strong disapproval of existing policy and behaviour in Darfur.

Similar to the grassroots efforts at divestment during the struggle against the Apartheid regime in South Africa, the movement for divestment in Sudan, mostly by groups in western countries is also important but should be complemented by similar movements sponsored by civil society organisations with help from the AU headquarters where appropriate. Non-governmental organisations receiving funding from companies and/or organisations whose income are derived from investment in the Sudan should refuse such funding in solidarity with the Darfuris. Collectively, African nations should not only cease doing business with companies identified as enhancing the capacity of the Sudanese government's unwillingness to negotiate in good faith, but divest from them, going so far as to freeze the accounts of Chinese, Malaysian, Indian, and other states' corporations that do not end their business with the government of Sudan. Recalling African ambassadors from major states - especially China and Russia, which are involved in the sensitive business of oil exploration, providing arms, weapons, and other support indirectly to the Janjaweed through the government of Sudan - would constitute a form of recognition withdrawal that will signal the seriousness of the AU's desire to end large-scale conflicts in the continent. Additionally, a bold move against the Sudanese government would be the withdrawal of all AU member ambassadors and diplomats from Khartoum. In a sense, African de-legitimisation of the Sudanese state is predicted to intensify a crisis of identity for the ruling elites and might hasten an internal change of government for a more progressive one willing to work within the principles of the AU to protect the rights of all citizens within its member states. The recent AU decision to deny Sudan its bid to serve as the chair of the Union is a positive example of a unified strategy for sending a message of disapproval. Similar actions as suggested above would throw Sudan into shock. The AU must look to approve and encourage any and all possible strategic moves within its power and charter to force the parties back to the negotiating table on the Darfur Peace Agreement (DPA) signed May 5, 2006.

Since both the Government of Sudan and the Sudanese Liberation Army/ Movement that signed the document have broken and violated its provisions 
several times and since many of the Darfuris rebels have splintered into different factions, the AU must facilitate a renegotiation of the agreement. This effort assumes that a cease-fire as previously argued is enforced. As several reports as well as the continuing violence indicate, the growing factional divide since the drafting of the DPA shows a lack of political will and faith in its implementation. Therefore, the AU must take the lead in negotiations and diplomatic efforts to consolidate the numerous existing efforts (by Chad, Libya, Eritrea, and the UN) into a single plan under the AU umbrella. A recent Human Rights Watch report reiterated the need for the UN, Arab League, Government of Sudan, EU, and others to support the efforts of the African Union to maintain and expand its efforts of achieving peace in Darfur as well as keeping the organisation's effective existence afloat (Human Rights Watch 2006:9-10). Again, the importance of the AU's role in bringing about a successful result to any agreement requires maintenance and expansion of their current monitoring role to one of ceasefire enforcement. The AU will succeed in its efforts at cease-fire enforcement and peaceful negotiation that ends the conflict and paves the way for political settlement of the Darfur crisis if practical strategies include confidence building among members of the various factions and communities within a familiar framework of local traditions. As Murithi (2005:76) notes, 'For peace to be sustainable there needs to be a process of consultation and involvement of local grassroots populations as part of the process of re-emphasizing the inherent worth of traditions. This will encourage confidence building and the establishment of trust and credibility for both the cease-fire enforcement and the eventual process of negotiating a lasting and sustainable peace in Sudan. Indeed, not paying attention to existing traditions and structures is the very problem that has plagued most of the approaches to development, economics, and politics in the continent. Ignoring existing structures and traditions implemented to deal with diverse situations as was the case in Darfur only intensifies conflicts whose origins and solutions are alien to the people whose lives are supposed to be transformed. By learning from and including traditional methods, the AU can capitalise on the rich history of enduring African cultures and methods of conflict resolution and management, and revitalise them as a parallel to formal 
$\mathrm{AU}$ approaches to conflict management and peace enforcement, especially in less developed regions of the continent like Darfur.

The African Union already has an ally on the ground to effectively begin a robust counter-strategy to the Sudanese government's policies of reneging on the responsibility to protect obligation. Reports from the Christian Science Monitor indicate that, after promises of land, cattle, and money proved to be worthless, 'dozens of Janjaweed commanders [and their troops] are joining the struggle against the Sudanese government' (Crilly 2007). This is a clear indication that if salient issues for each party, as previously argued, are identified and addressed, the crisis could be controlled. These defectors have played a crucial role in helping protect the roads from attacks, allowing convoys of food and humanitarian aid through to rural and formerly dangerous areas. By tapping into this group of sympathetic Sudanese Arabs, particularly those who have disassociated themselves from the Janjaweed and are working to protect civilians or defending them by joining SLA or JEM, the AU can identify those who still have ties to the Janjaweed and central government and place pressure on them to prepare for meaningful talks. These defectors and many other Sudanese 'Arab' tribes exist within the Darfur region and have continuously opposed the Government of Sudan policy and refused to take part in the actions of the Janjaweed (Crilly 2007). Comprehensive talks would require these Arab groups to be involved and represented as a show of Darfurian unity and rejection of the entirely 'ethnic' nature of the conflict; as Prunier aptly notes, ethnic tensions 'were the raw materials, not the cause' (Prunier 2006:200) of the large-scale violence in Darfur.

Clearly, there are strategic religious dimensions to the conflict in Darfur, but these need to be clarified to make sense of the recommendation below. The North-South conflict in Sudan since 1956 pitted Arab Muslims (north) against Black Christians (south); but the case of Darfur is different because the National Islamic Front (NIF) that controls the government of Sudan is engaged in a large-scale violence against Darfuris who are mostly Africans, but also Muslims. Therefore, considering the Islamist roots of the NIF and al-Bashir's regime, the AU should counter its religious basis for power by strategically and diplomatically making the case that another Muslim-versus-Muslim conflict would shadow 
the sectarian violence in Iraq. Also, the looming civil war among Palestinians is an affront to Islam and the unity of the 'ummah' or Muslim world. This is important since the NIF balks at claims of rape by Janjaweed members, or at least government support for it, as impossible and 'un-Islamic'. This requires the inclusion of predominantly Muslim African nations such as Libya, Egypt, Tunisia, Algeria, and others who also hold seats in both the Arab League and the $\mathrm{AU}$ to use their influence in discussions with Sudan to compel the al-Bashir regime to ensure the protection of the Darfuris against rape, torture, murder and ethnic cleansing by other Muslims. The same can be said of Christian on Christian violence, as was the case in Rwanda.

In the end, the various actors in the Darfur crisis, especially states, are only likely to act when compelled by either positive or negative incentives to change their behaviour; and in contemporary international politics, only the US has the capability and credibility of action to effectively engage the various actors to resolve the Darfur crisis. But as was painfully pointed out by a guest on Wolf Blitzer's Situation Room, in the realist world of politics, countries, including the US, never choose friends, but rather whatever is in their national interest at the time (Blitzer 2007). The question is: Does the responsibility to protect factor into the national interest of the United States, Russia, China and other capable major powers who are directly or indirectly involved with the Government of Sudan? The answer for now is no!

Therefore, the responsibility to protect, especially Africans, falls to the African Union. Its potential for doing well is boundless. At the least, the AU can succeed in establishing optimism and 'override the sense of inevitability of crisis which has framed the way Africans and non-Africans have viewed the continent for decades' (Murithi 2005:106). Its premise of Pan-Africanism and unity can be a way for the AU to convince Sudan to take strong steps to end the terror of the Janjaweed and prepare for a viable end to the conflict. In the meantime, 'focusing on stabilizing Darfur in time for the 2009 midterm elections, security, political, and humanitarian assistance efforts must be supported by adequate funding and logistical support' (United Nations Security Council 2007) $)^{9}$ by African states,

9 See also Murray 2004:268. 
especially South Africa, Nigeria, Egypt and Libya that have professed a desire to see an end to the violence in Darfur.

The AU has the tools it needs to become a solid entity in mediating African issues. It gains strength from the collective desire to uphold the responsibility to protect principle enshrined in both the UN and AU pronouncements. For the international community, especially members of the EU, NATO and the UN and for capable states such as the United States of America, the African Union has shown the desire to uphold the responsibility to protect. This is evidenced by their willingness to supply the troops for peace enforcement, but the AU lacks what those groups and nations have - robust and credible logistical equipment like helicopters, weapons and money to pay an over-stretched, underpaid, and unprepared African force - to succeed in an action that is clearly the collective responsibility of the international community if the UN Charter is to remain credible. For the AU, success can occur through logistic and financial support for the proposed hybrid UNMIS/AMIS force as well as the restart of peace talks as specified above. However, for a sustained capacity to influence external entities to help with African problems, or at least to not block action, especially at the Security Council, the AU should not hesitate to look beyond Africa for pressure and influence to force parties back to the table to make real decisions. Thus the AU maintains its position of leadership. An international community which focuses on African issues should be strategically institutionalised by funding an Africa Advocacy group in various countries - especially in those countries whose citizens and corporations are likely to be spoilers for African issues and policies in the international system. In the end, the assertion that only when Africa is neglected will it look to solve its own problems (Francis 2005:123), may be true here as the large-scale violence in Darfur did not become a major issue in much of the press in Africa until the international media picked up the cause in 2004. However the issue came to be a major event for Africa, its resolution requires the collective efforts of Africans, civil society organisations, governments, media, intellectuals and yes, external actors and organisations like the African Union to find a sustainable solution to crimes against humanity in the continent; so rather than yet again in Africa, we can say, NEVER AGAIN! 


\section{Sources}

Adibe, Clement E. 2007. Once Bitten, Twice Shy: The Evolution of U.S. Policy on the Crisis in the Darfur Region of Sudan. Paper presented at the annual meeting of the International Studies Association (ISA), Chicago, IL, 28 Feb - 3 Mar 2007.

African Union 2000. Constitutive Act of the African Union, 11 July 2000.

African Union 2002. Protocol Relating to the Establishment of the Peace and Security Council of the African Union, 1st Ordinary Session of the Assembly of the African Union, 9 July 2002. Available at <http://www.africa-union.org/root/au/organs/psc/Protocol_peace $\% 20$ and\%20security.pdf $>$

African Union 2006. Darfur Peace Agreement, 5 May 2006. Available at <http://www.umis.org/ english/dpa.htm>

Akol, Lam 1987. The Present War and its Solution. In: Deng, Francis \& Prosser Gifford (eds), Search for Peace and Unity in the Sudan. Washington, DC: The Woodrow Wilson Center Press.

Al-Baqir al-Afif Mukhtar 2007. The Crisis of Identity in Northern Sudan: A Dilemma of a Black People with a White Culture. A paper presented at the CODESRIA African Humanities Institute.

Blitzer, Wolf 2007. The Situation Room. Cable News Network. 12 June 2007.

Crilly, Rob 2007. In Darfur, Some Arabs Now Fight Alongside Rebels. The Christian Science Monitor, 22 May 2007. Available at <http://news.yahoo.com/s/csm/20070522/wl_csm/ oswitch_1>

Daly, M.W. 2007. Darfur's Sorrow: A History of Destruction and Genocide. New York: Cambridge University Press.

Francis, David J. 2005. Uniting Africa: Building Regional Peace and Security Systems. Burlington: Ashgate.

Human Rights Watch 2006. Imperatives for Immediate Change: The African Union Mission in Sudan. Human Rights Watch 18 (1 A)

Independent International Commission on Kosovo 2000. The Kosovo Report: Conflict, international Response, Lessons Learned. Oxford: Oxford University Press.

Jentleson, Bruce W. 2007. American Foreign Policy: The Dynamics of Choice in the 21st Century. Third Edition. New York: W.W. Norton \& Co.

Kasfir, Nelson 2005. Sudan's Darfur: Is it Genocide? Current History, May 2005.

Kristof, Nicholas 2005. The Secret Genocide Archive. The New York Times, 23 Feb 2005. Available at <http://www.nytimes.com/2005/02/23/opinion/23kristof.html >

Levitt, Jeremy 2005. The Peace and Security Council of the African Union, the Use of Force and the United Nations Security Council: The Case of Sudan. In: Blokker, Niels \& Nico Schrijver (eds), The Security Council and the Use of Force: Theory and Reality - A Need for Change? Leiden: Martinus Nijhof. 
Murithi, Timothy 2005. The African Union: Pan-Africanism, Peacebuilding and Development. Burlington: Ashgate.

Murray, Rachel 2004. Human Rights in Africa: From the OAU to the African Union. Cambridge: Cambridge University Press.

Prunier, Gerard 2006. The Politics of Death in Darfur. Current History, May 2006.

Republic of Sudan, Ministry of Social Affairs 1958. First Population Census of Sudan 1955/56, Last (9th) interim report. Khartoum: Population Census Office.

Straus, Scott 2005. Darfur and the Genocide Debate. Foreign Affairs 84 (1).

The Economist 2007. Pity the people of Darfur, pity the peacemakers too. The Economist Vol. 385, Issue 8552 (27 Oct 2007).

United Nations Security Council 2007. Report of the Secretary-General on the Sudan (S/2007/213), 17 April 2007.

Zweifel, Thomas D. 2006. International Organizations and Democracy: Accountability, Politics, and Power. Boulder: Lynne Rienner. 
